\title{
Penerapan Model Pembelajaran Kooperatif Tipe Team Games Tournament Untuk Meningkatkan Pemahaman Siswa Kelas X SMK Negeri 1 Mantangai Terhadap Materi Tata Nama Senyawa Kimia Sederhana Tahun Pelajaran 2016/2017
}

\author{
Murjani \\ SMKN 1 Mantangai, Jl. Kahayan Blok C Lamunti Permai A-1 Mantangai, \\ Kapuas, Kalimantan Tengah, Indonesia \\ Email:murjani.ajan@gmail.com
}

\begin{abstract}
Abstrak. Telah dilakukan penelitian tentang penerapan model pembelajaran kooperatif tipe team games tournament (TGT) terhadap materi tata nama senyawa pada kelas XB SMK Negeri 1 Mantangai. Penelitian ini bertujuan untuk (1) mengetahui peningkatan pemahaman siswa terhadap materi tata nama senyawa dan (2) mengetahui respon siswa terhadap penerapan model pembelajaran kooperatif tipe TGT pada pembelajaran. Penelitian ini menggunakan rancangan penelitian tindakan kelas dengan 2 siklus. Subjek penelitian adalah siswa kelas XB SMK Negeri 1 Mantangai dengan jumlah siswa sebanyak 25 orang. Data dikumpulkan melalui teknik tes dan angket yang selanjutnya dianalisis menggunakan teknik persentase. Penelitian ini dikatakan berhasil jika $75 \%$ dari jumlah siswa mencapai taraf penguasaan $\geq 75$ dari materi yang diajarkan. Hasil penelitian menunjukkan bahwa (1) penerapan model pembelajaran kooperatif tipe TGT dapat meningkatkan pemahaman siswa pada materi tata nama senyawa kimia sederhana. Terjadi peningkatan ketuntasan dari siklus I ke siklus II yakni dari $62 \%$ menjadi $86 \%$ dan rata-rata nilai siswa meningkat dari 65,8 menjadi 85,8 (2) siswa memberikan respon positif terhadap proses pembelajaran tata nama senyawa yang diajarkan menggunakan model pembelajaran kooperatif tipe TGT.

Kata kunci: Team Games Tournament, pemahaman, tata nama senyawa.
\end{abstract}

\section{PENDAHULUAN}

Salah satu konsep kimia yang dipelajari di kelas X SMK Pertanian pada semester 2 adalah konsep tata nama senyawa kimia. Berdasarkan studi pendahuluan yang dilakukan peneliti terhadap pembelajaran tata nama kimia sederhana di kelas X SMKN 1 Mantangai tahun 2016 merupakan salah satu konsep yang sulit bagi siswa dengan tingkat penguasaan rata-rata 66,3.

Proses pembelajaran yang dilakukan untuk sementara ini masih menggunakan model pembelajaran konvensional. Daya serap siswa terhadap konsep ini masih belum maksimal dimana dalam satu kelas hanya sebagian dari siswa saja yang dapat menguasai materi tersebut dengan baik, bahkan siswa yang telah naik ke kelas XI masih banyak yang belum dapat memberi nama terhadap senyawa yang sudah disebutkan rumus molekulnya.

Salah satu cara untuk mengatasi permasalahan di atas adalah dengan mengkondisikan pembelajaran sedemikian rupa agar pembelajaran menjadi lebih bervariasi dan menarik bagi siswa sehingga siswa mendapatkan suatu kemudahan 
dan merasa senang dalam belajar konsep tata nama senyawa kimia sederhana. Hal ini dapat dipahami, karena rasa senang dalam belajar merupakan kunci sukses dalam menguasai pelajaran secara utuh dan baik.

Penelitian ini menerapkan model pembelajaran kooperatif tipe TGT untuk meningkatkan pemahaman siswa kelas XB SMKN 1 Mantangai tentang tata nama senyawa kimia sederhana.

\section{KAJIAN PUSTAKA}

TGT adalah salah satu tipe pembelajaran kooperatif yang menempatkan siswa dalam kelompok-kelompok belajar yang beranggotakan 5 sampai 6 orang siswa yang memiliki kemampuan, jenis kelamin dan suku atau ras yang berbeda. Bentuk TGT hampir sama dengan STAD, perbedaannya adalah dalam TGT tidak dilakukan tes kuis atau saling tanya tetapi digunakan turnamen atau permainan. Guru menyajikan materi dan siswa bekerja dalam kelompok mereka masingmasing.

Langkah-langkah pembelajaran dalam model pembelajaran kooperatif tipe TGT (Kiranawati, 2007) adalah sebagai berikut: (1) presentasi, (2) tim studi, (3) turnamen, (4) para siswa kembali lagi ke kelompok tim studi mereka dan melaporkan hasil mereka peroleh pada waktu bertanding; dan (5) penghargaan,

Teknis jalannya pengelompokkan siswa pada model pembelajaran kooperatif tipe TGT dapat dilihat pada Gambar 1, sedangkan teknis permainan model pembelajaran kooperatif tipe TGT pada tiap meja turnamen dapat dilihat pada Gambar 2.

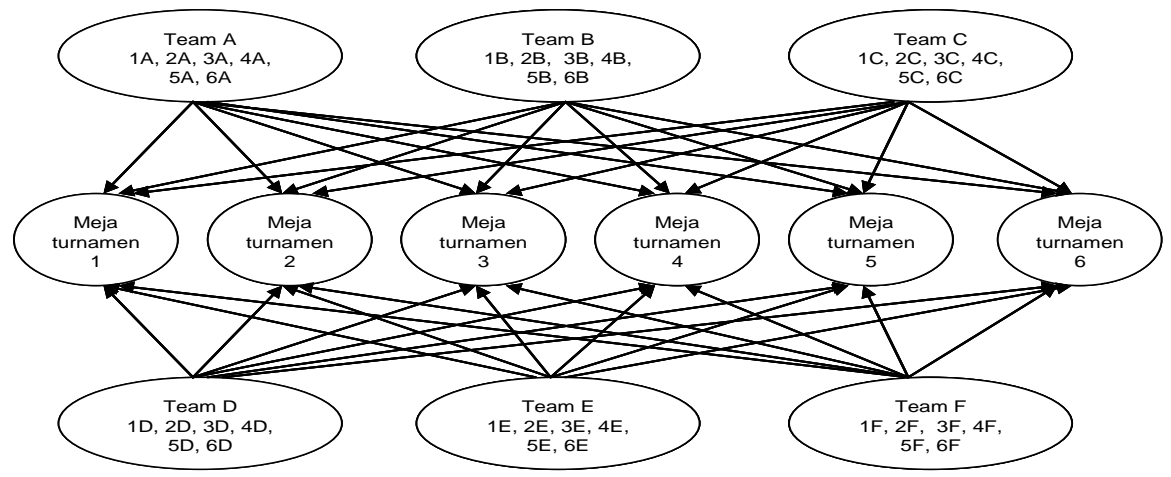

Gambar 1 Teknis pengelompokkan siswa dalam model pembelajaran kooperatif tipe TGT

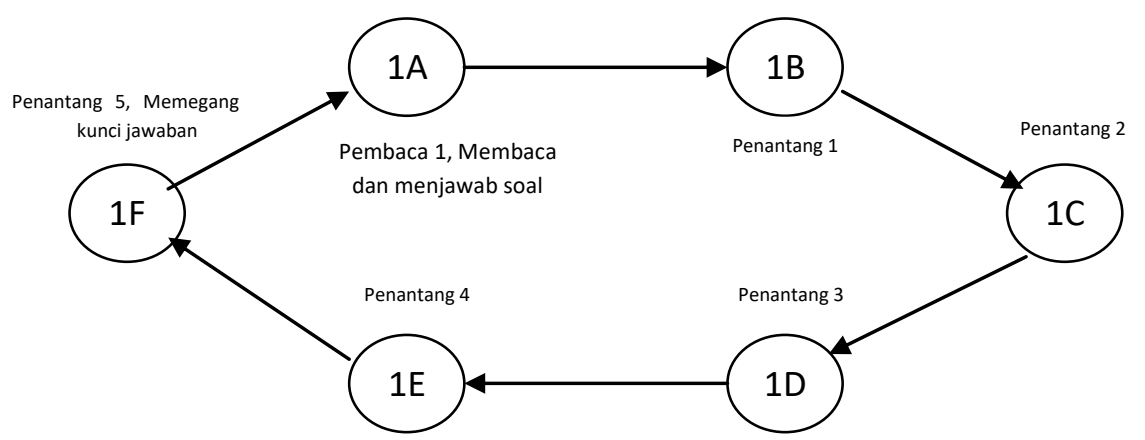

Gambar 2 Teknis permainan model pembelajaran kooperatif tipe TGT pada tiap meja turnamen 


\section{METODE PENELITIAN}

Penelitian ini menggunakan rancangan penelitian tindakan kelas (classroom action research). Penelitian ini menginginkan terjadinya perbaikan, peningkatan dan perubahan proses ataupun hasil belajar yang lebih baik agar tujuan pembelajaran dapat tercapai secara optimal.

Siklus I dan siklus II dilaksanakan dalam dua kali tindakan kelas, sehingga untuk 2 siklus terdapat empat kali tindakan kelas. Pembelajaran siklus II melihat refleksi dari evaluasi siklus I, yakni kekurangan yang ditemukan dari hasil evaluasi pada siklus I, terutama pada pelaksanaan model pembelajaran kooperatif tipe TGT terhadap materi selanjutnya. Tiap siklus terdiri dari tahapan-tahapan : (1) perencanaan (planning), (2) pelaksanaan tindakan (action), (3) observasi dan evaluasi, serta (4) analisis dan refleksi. Evaluasi dilakukan setelah siklus I dan siklus II selesai. Evaluasi ini merupakan hasil dari tingkat pemahaman siswa terhadap konsep tata nama senyawa kimia sederhana.

Penelitian ini dilaksanakan dari bulan Januari 2017 sampai Juli 2017, di kelas XB SMKN 1 Mantangai. Tindakan kelas ini dilaksanakan pada tanggal 16 Januari - 09 Pebruari 2017. Subjek penelitian adalah siswa-siswi kelas XB dengan jumlah siswa sebanyak 25 orang, yang terdiri dari 13 orang siswa dan 12 orang siswi dengan tingkat kemampuan dan daya serap siswa yang sangat bervariasi. Data dikumpulkan menggunakan teknik tes tertulis berupa pilihan ganda, Observasi, dan angket.

Instrumen yang digunakan untuk mengukur tingkat pemahaman siswa tentang konsep tata nama senyawa kimia sederhana dalam bentuk tes objektif sebanyak 25 soal dan angket respon siswa berupa angket respon positif. Prosedur penelitian tindakan kelas berupa perencanaan, pelaksanaan tindakan, observasi dan evaluasi, serta analisis dan refleksi.

Teknik analisis data penguasaan dan persentase respon siswa menggunakan rumus : Persentase penguasaan siswa $=\frac{f}{N} \times 100 \%$. Penelitian ini dikatakan berhasil jika $75 \%$ dari jumlah siswa mencapai taraf penguasaan $\geq 75$ dari materi yang diajarkan.

\section{HASIL PENELITIAN DAN PEMBAHASAN}

Evaluasi kelompok pada siklus I didapatkan setelah dilakukan pertandingan. Hasil evaluasi kelompok tersebut dapat dilihat pada Tabel 1.

Tabel 1 Hasil penilaian kelompok pada pembelajaran siklus I

\begin{tabular}{|c|c|c|c|}
\hline Kelompok & $\begin{array}{c}\text { Perolehan } \\
\text { Jumlah Kartu } \\
\text { pada TGT I }\end{array}$ & $\begin{array}{c}\text { Skor rata-rata } \\
\text { anggota } \\
\text { kelompok }\end{array}$ & Peringkat \\
\hline A & 12 & 2,00 & III \\
B & 14 & 2,33 & I \\
C & 9 & 1,50 & IV \\
D & 13 & 2,17 & II \\
E & 12 & 2,00 & III \\
\hline
\end{tabular}

Tabel 1 menunjukkan bahwa kelompok yang mendapat nilai tertinggi pada turnamen I dengan perolehan jumlah kartu 14 dan mendapat predikat sebagai juara I adalah kelompok B. Predikat juara II diraih oleh kelompok D, dan predikat 
juara III diraih oleh kelompok A dan E, sedangkan kelompok yang memperoleh jumlah kartu terendah dengan jumlah kartu 9 adalah kelompok $\mathrm{C}$.

Hasil pertandingan pada siklus I masih kurang, ini terlihat dari kurangnya jumlah kartu jawaban yang diperoleh siswa. Banyaknya kartu jawaban yang diperoleh siswa yang tertinggi hanya 14 kartu atau sekitar 26,9\% dari 52 kartu jawaban yang disediakan.

Hasil evaluasi individu pada siklus 1 diperoleh data seperti pada Gambar 3.

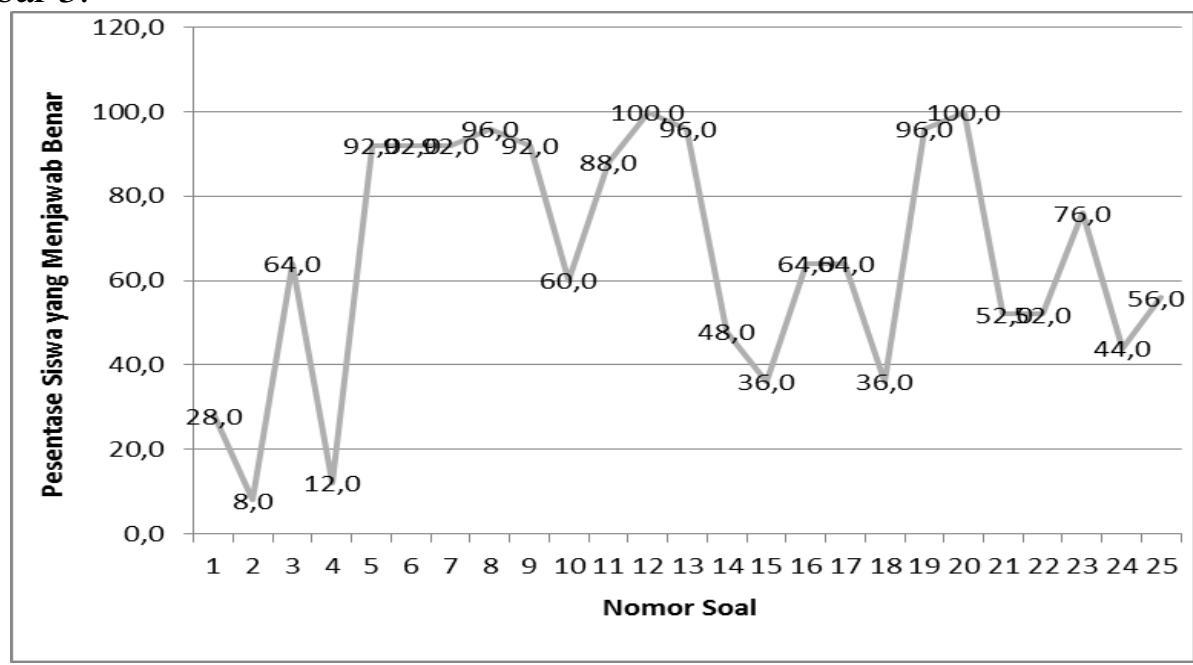

Gambar 3 Hasil evaluasi pembelajaran siklus I

Distribusi tingkat penguasaan siswa dapat dilihat pada Tabel 6 dan hasil belajar siswa berdasarkan kriteria keberhasilan penelitian tindakan kelas dapat dikelompokkan seperti pada Tabel 2 berikut.

Tabel 2 Distribusi tingkat penguasaan siswa setelah siklus I

\begin{tabular}{|c|c|c|c|c|}
\hline No & $\begin{array}{c}\text { Tingkat } \\
\text { penguasaan }\end{array}$ & Kriteria & $\begin{array}{c}\text { Jumlah } \\
\text { siswa }\end{array}$ & $\begin{array}{c}\text { \% } \\
\text { siswa }\end{array}$ \\
\hline 1. & $86-100$ & Sangat Baik & 0 & 0 \\
2. & $71-85$ & Baik & 10 & 40 \\
3. & $56-70$ & Cukup & 11 & 44 \\
4. & $\leq 55$ & Kurang & 4 & 16 \\
\hline
\end{tabular}

Tabel 3 Hasil belajar siswa berdasarkan kriteria keberhasilan tindakan siklus I

\begin{tabular}{|c|c|c|}
\hline Tingkat penguasaan & $\begin{array}{c}\text { Jumlah } \\
\text { siswa }\end{array}$ & \% siswa \\
\hline$\geq 75$ & 7 & 28,0 \\
\hline$<75$ & 18 & 72,0 \\
\hline Jumlah total & 25 & 100,0 \\
\hline
\end{tabular}

Penguasaan siswa pada siklus 1 tergolong kurang karena taraf penguasaan siswa belum mencapai indikator keberhasilan (lihat Tabel 3). Hasil pembelajaran siklus I belum baik, ini terlihat dari hasil tes individu setiap siswa masih ada yang gagal dan belum cukup baik. Dilihat dari pencapaian permainan juga sangat kurang karena jumlah kartu jawaban yang diperoleh siswa tidak banyak. 
Berdasarkan fakta-fakta tersebut, hal yang perlu diperbaiki dalam pelaksanaan siklus II adalah meningkatkan kerjasama siswa di dalam kelompoknya masing-masing, meningkatkan efisiensi waktu, intensitas pembelajaran pada segmen materi yang masih kurang dikuasai oleh siswa misalnya lebih menekankan pada penyebutan nama-nama dan rumus senyawa kimia sederhana.

. Evaluasi yang diberikan perkelompok pada pembelajaran siklus II menghasilkan data seperti pada Tabel 4.

Tabel 4 Hasil penilaian kelompok pada pembelajaran siklus II

\begin{tabular}{|c|c|c|c|}
\hline Kelompok & $\begin{array}{c}\text { Perolehan } \\
\text { Jumlah Kartu } \\
\text { pada TGT II }\end{array}$ & $\begin{array}{c}\text { Skor rata-rata } \\
\text { anggota } \\
\text { kelompok }\end{array}$ & Peringkat \\
\hline A & 22 & 3,67 & IV \\
B & 25 & 4,17 & II \\
C & 24 & 4,00 & III \\
D & 27 & 4,50 & I \\
E & 25 & 4,17 & II \\
\hline
\end{tabular}

Tabel 4 menunjukkan bahwa kelompok yang mendapat nilai tertinggi pada turnamen II dengan perolehan jumlah kartu 27 dan mendapat predikat sebagai juara I adalah kelompok D. Predikat juara II diraih oleh kelompok B dan E, dan predikat juara III diraih oleh kelompok C, sedangkan kelompok yang memperoleh jumlah kartu terendah dengan jumlah kartu 9 adalah kelompok A.

Hasil pertandingan pada siklus II ini sebenarnya sudah cukup ini terlihat dari banyaknya jumlah kartu jawaban yang diperoleh siswa. Banyaknya kartu jawaban tertinggi yang diperoleh siswa ada 27 kartu dari 52 kartu jawaban yang disediakan atau sekitar 51,9\% dari semua jumlah kartu yang disediakan. Artinya dari semua kartu tersebut, setengahnya sudah dapat dijawab siswa. Secara keseluruhan dari permainan ini dianggap sesuai karena sudah menunjukkan adanya peningkatan jumlah perolehan kartu serta kerjasama anggota kelompok dan rasa tanggung jawabnya terhadap kelompok juga terlihat semakin meningkat walaupun masih perlu ditingkatkan lagi.

Hasil evaluasi individu pada postes 2 ini diperoleh data seperti pada Gambar 4.

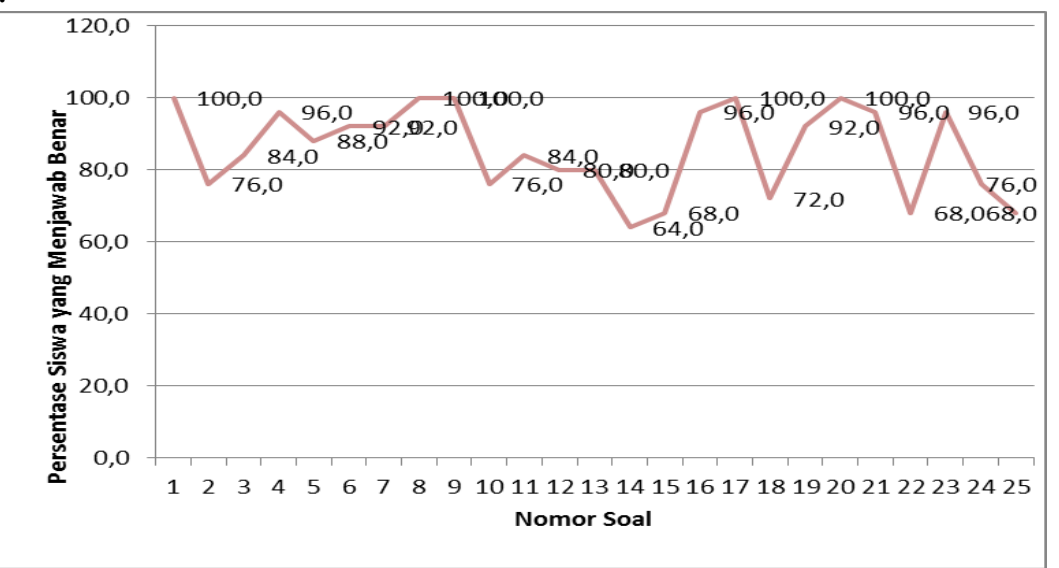

Gambar 4 Hasil evaluasi pembelajaran siklus II 
Gambar 4 menunjukkan bahwa rata-rata persentase keberhasilan siswa pada pembelajaran siklus II ini mengalami peningkatan. Menurut Tim Diknas Kalsel (2004) semua indikator yang dibuat sudah dapat dikuasai siswa karena persentase rata-rata tiap indikator masuk dalam kriteria baik, amat baik dan bahkan istimewa.

Secara keseluruhan perbedaan tingkat pemahaman siswa antara siklus I dan siklus II terlihat Gambar 5.

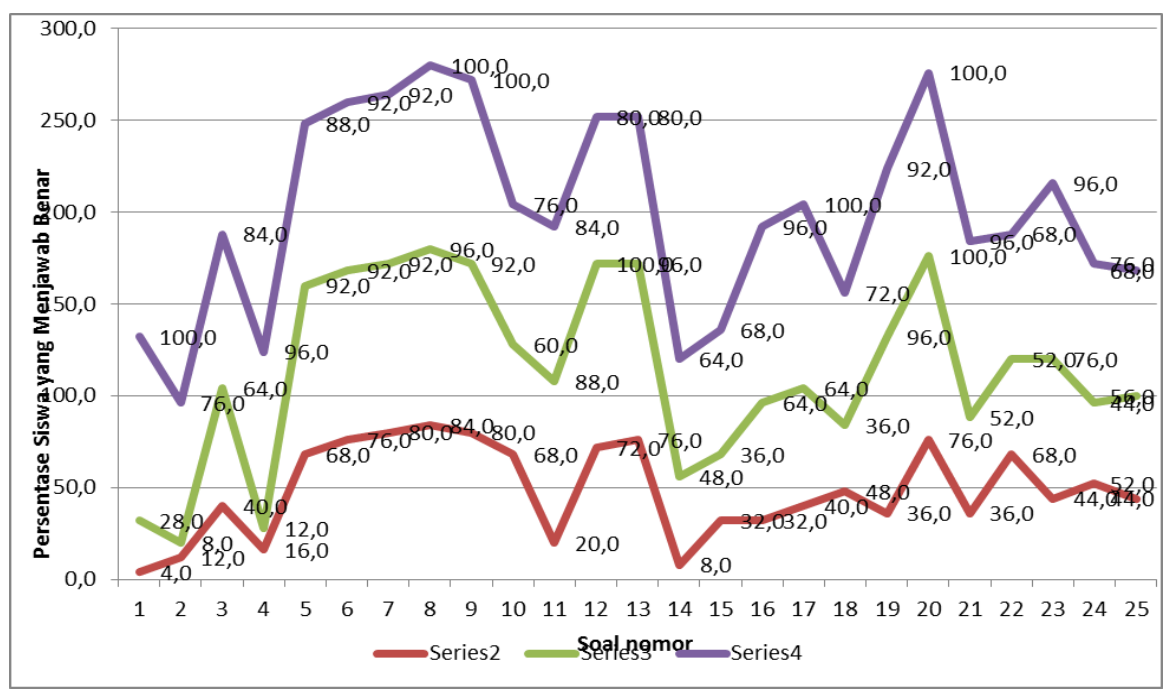

Gambar 5 Perbandingan Tingkat pemahaman siswa pada siklus I dan II

Gambar 5 menunjukkan pencapaian terhadap seluruh indikator pembelajaran sudah memenuhi kriteria keberhasilan. Kekurangan yang terdapat pada siklus I telah dapat diperbaiki pada siklus II. Hal ini terlihat dengan meningkatnya tingkat pemahaman siswa walaupun telah mencapai taraf indikator keberhasilan tetap masih perlu ditingkatkan kembali karena masih ada materi yang belum maksimal dikuasai oleh siswa.

Distribusi tingkat penguasaan siswa pada siklus II dapat dilihat pada Tabel 5 dan hasil belajar siswa berdasarkan kriteria keberhasilan penelitian tindakan kelas dapat dikelompokkan seperti pada Tabel 6.

Tabel 5 Distribusi tingkat penguasaan siswa pada siklus II

\begin{tabular}{|c|c|c|c|c|}
\hline No & $\begin{array}{c}\text { Tingkat } \\
\text { penguasaan }\end{array}$ & Kriteria & $\begin{array}{c}\text { Jumlah } \\
\text { siswa }\end{array}$ & \% siswa \\
\hline 1. & $86-100$ & Sangat & 13 & 52 \\
2. & $71-85$ & Baik & 11 & 44 \\
3. & $56-70$ & Baik & 1 & 4 \\
4. & $\leq 55$ & Cukup & 0 & 0 \\
\hline
\end{tabular}

Tabel 6 Hasil belajar siswa berdasarkan kriteria keberhasilan tindakan siklus II

\begin{tabular}{|c|c|c|}
\hline Tingkat penguasaan & $\begin{array}{c}\text { Jumlah } \\
\text { siswa }\end{array}$ & \% siswa \\
\hline$\geq 75$ & 23 & 92,0 \\
\hline$<75$ & 2 & 8,0 \\
\hline Jumlah total & 25 & 100,0 \\
\hline
\end{tabular}


Rata-rata penguasaan siswa pada siklus II terhadap pembelajaran konsep tata nama senyawa kimia sederhana dengan model kooperatif tipe TGT sudah memenuhi kriteria keberhasilan karena sebanyak 92,0\% siswa sudah memenuhi nilai $\geq 75$, ini terlihat karena siswa sudah banyak mengerti tentang konsep tata nama senyawa kimia sederhana tersebut.

Perolehan skor rata-rata jumlah kartu pada siklus II lebih baik dari siklus I karena masing-masing anggota kelompok saling bekerja sama dengan baik dan adaptasi siswa terhadap model pembelajaran kooperatif tipe TGT sudah semakin baik, meskipun ada beberapa kelompok yang masih kurang dan mengalami penurunan dalam pencapaian skor. Perhatian dan kerjasama antara siswa yang satu dengan siswa yang lain pada saat menjawab pertanyaan yang terdapat dalam LKS juga meningkat dan keberanian siswa dalam mengajukan pertanyaan kepada temannya meningkat saat diskusi berlangsung sehingga hasil evaluasi rata-rata per individu dilihat dari kriteria keberhasilannya sudah sangat baik yakni sebesar 85,8 .

Respon siswa terhadap pembelajaran pada konsep tata nama senyawa kimia sederhana dengan menggunakan model pembelajaran kooperatif tipe TGT dapat dilihat pada Gambar 6 berikut.

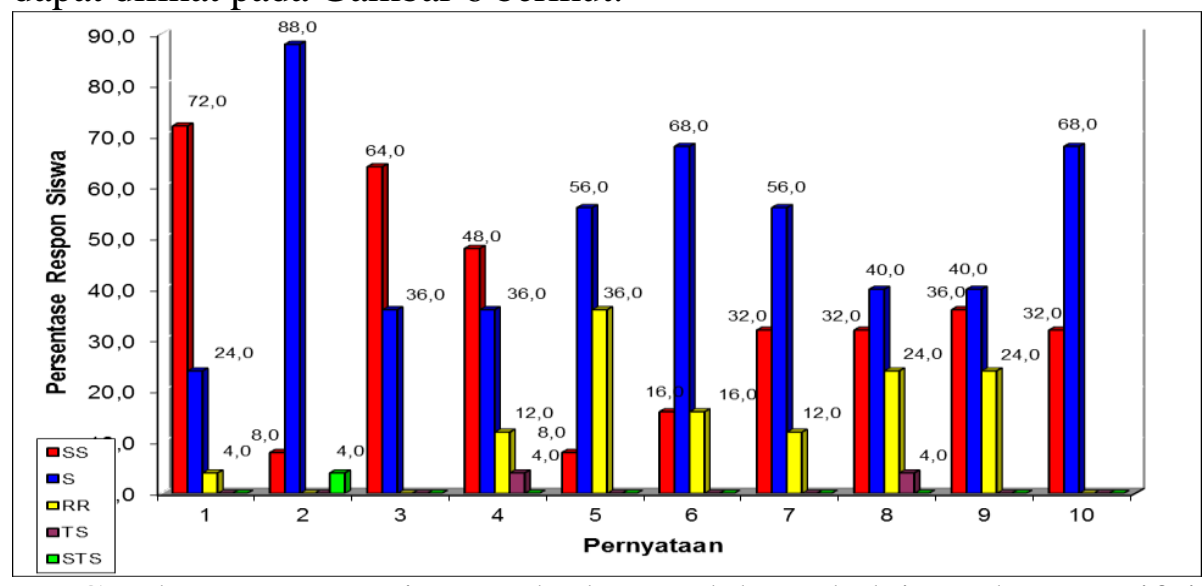

Gambar 6 Respon siswa terhadap model pembelajaran kooperatif tipe TGT

Distribusi penilaian respon siswa terhadap model pembelajaran kooperatif tipe TGT dapat dilihat pada Tabel 7.

Tabel 7 Distribusi respon siswa terhadap model pembelajaran kooperatif tipe TGT

\begin{tabular}{|c|c|c|c|}
\hline Skor & Kriteria & Jumlah Siswa & $\%$ siswa \\
\hline $42,8-50,0$ & Sangat Baik & 15 & 60,0 \\
\hline $34,6-41,8$ & Baik & 10 & 40,0 \\
\hline $26,4-33,6$ & Ragu-Ragu & 0 & 0 \\
\hline $18,2-25,4$ & Tidak Baik & 0 & 0 \\
\hline $10,0-17,2$ & Sangat Tidak Baik & 0 & 0 \\
\hline
\end{tabular}

Rata-rata skor yang diperoleh siswa pada Tabel 7 menunjukkan bahwa $100 \%$ siswa mengatakan baik dan sangat baik jika pembelajaran tata nama senyawa kimia sederhana menggunakan model pembelajaran kooperatif tipe TGT. 
Penguasaan siswa pada siklus II sudah mencapai indikator keberhasilan yaitu sebanyak $92,0 \%$ siswa telah mencapai nilai $\geq 75$ (lihat Tabel 6). Hasil pembelajaran siklus II sudah baik, ini terlihat dari meningkatnya tingkat pemahaman siswa dan dari pencapaian permainan juga terjadi peningkatan.

Hasil analisis tindakan pada siklus II menunjukkan bahwa terjadi peningkatan pemahaman dan respon siswa terhadap penggunaan model pembelajaran kooperatif tipe TGT pada materi tata nama senyawa kimia sederhana. Dengan demikian dapat disimpulkan bahwa:

(1) model pembelajaran kooperatif tipe TGT ini dapat diterapkan sebagai salah satu model pembelajaran kimia untuk meningkatkan pemahaman siswa pada konsep tersebut;

(2) tingkat pemahaman siswa diduga masih dapat ditingkatkan melalui penambahan siklus dan peningkatan proses pembelajaran.

\section{SIMPULAN}

Berdasarkan hasil tindakan kelas terhadap kelas XB SMK Negeri 1 Mantangai disimpulkan:

1. Penerapan model pembelajaran kooperatif tipe TGT dapat meningkatkan pemahaman siswa tentang tata nama senyawa. Terjadi peningkatan ketuntasan dari siklus I ke siklus II yakni dari $28,0 \%$ menjadi $92,0 \%$ dan rata-rata nilai siswa meningkat dari 65,8 menjadi 85,8.

2. Siswa memberikan respon positif terhadap proses pembelajaran tata nama senyawa yang diajarkan menggunakan model pembelajaran kooperatif tipe TGT.

\section{DAFTAR RUJUKAN}

Arifin, Z. 1990. Evaluasi Instruksional. Remaja Rosdakarya, Bandung.

Arikunto, S. 1998. Prosedur Penelitian Suatu Pendekatan Praktek. Edisi Revisi Ke-IV. Rineka Cipta, Jakarta. 2003. Dasar-Dasar Evaluasi Pendidikan. Edisi Revisi Ke-IV. Bumi Aksara, Jakarta.

Badan Standar Nasional Pendidikan (BSNP) dan Direktorat Pembinaan SMK dan Ditjen Mandiknasmen Depdiknas. 2006. Contoh-contoh Silabus KTSP. BSNP dan Depdiknas, Jakarta.

Badan Standar Nasional Pendidikan (BSNP). 2015. Prosedur Operasional Standar Penyelenggaraan Ujian Nasional. BSNP, Jakarta.

Dasna, I W. \& Sutrisno. 2006. Model-Model Pembelajaran Konstruktivistik dalam Pembelajaran Sains-Kimia. Universitas Negeri Malang, Malang.

Ernawati. 2005. Analisis Tingkat Penguasaan Konsep Tata Nama Kimia pada Siswa Kelas II SMP di Kabupaten Hulu Sungai Selatan Tahun 2004/2005. Skripsi Program S-1, Universitas Lambung Mangkurat, Banjarmasin. (tidak dipublikasikan).

http://ipotes.wordpress.com, 2008.

Ibrahim, H. M., Fida. R., M. Nur \& Ismono. 2000. Pembelajaran Kooperatif. University Press, Surabaya.

Ilma, N. 2006. Implementasi Perpaduan Model Jigsaw dan Team Games Tournament (TGT) dalam Pembelajaran Konsep Tata Nama Senyawa dan 
Persamaan Reaksi Sederhana pada Siswa Kelas X SMA Negeri 5 Banjarmasin. Skripsi Program S-1, Universitas Lambung Mangkurat, Banjarmasin. (tidak dipublikasikan).

Kiranawati, 2007. Metode Team Games Tournament (TGT).

http://gurupkn.wordpress.com.

Miyani. 2005. Implementasi Model Pembelajaran Kooperatif Tipe Team Games

Tournament (TGT) pada Konsep Larutan Asam Basa dalam Upaya

Meningkatkan Prestasi Belajar Siswa Kelas II MAN 2 Model Banjarmasin

Tahun Ajaran 2004/2005. Skripsi Program S-1, Universitas Lambung Mangkurat, Banjarmasin. (tidak dipublikasikan).

Nisa, K. 2004. Meningkatkan Prestasi Belajar dan Persepsi Siswa terhadap

Pelajaran Kimia dengan menggunakan Model Pembelajaran Team Games Tournament (TGT) dalam Materi Sistem Koloid pada Siswa Kelas II SMA Negeri 6 Banjarmasin Tahun Pelajaran 2003/2004. Skripsi Program S-1, Universitas Lambung Mangkurat, Banjarmasin. (tidak dipublikasikan)

Permana, I. 2008. Memahami Kimia SMK Kelompok Teknologi, Kesehatan dan Pertanian untuk Kelas X Semester 1 dan 2. Armico, Bandung.

Purba, M. 2006. IPA KIMIA untuk SMP Kelas VII. Erlangga, Jakarta.

Purba, M. 2007. KIMIA 1 untuk SMA Kelas X. Erlangga, Jakarta.

Purba, M. 2010. KIMIA Jilid I untuk SMK dan MAK Kelas X. Erlangga, Jakarta.

Ratumanan, T.G \& T. Laurens. 2003. Evaluasi Hasil Belajar yang Relevan dengan Kurikulum Berbasis Kompetensi. Unesa University Press Surabaya.

Sudjana, N. 1996. Cara Belajar Siswa Aktif dalam Proses Belajar Mengajar. Sinar Baru Algensindo, Bandung.

Sudijono, A. 2005. Pengantar Statistik Pendidikan. PT. Raja Grafindo Persada, Jakarta.

Winarti, A. 1999. Analisis Pemahaman Konsep Asam Basa melalui Penggambaran Mikroskopis dan Hubungannya dengan Kemampuan Berfikir Formal Mahasiswa Program Studi Pendidikan Kimia FKIP UNLAM Banjarmasin. Tesis Program Pasca Sarjana IKIP Malang, Malang. (tidak dipublikasikan). 